\title{
Gastric cancer screening - does it exist or not? - Literature review
}

\author{
Badanie przesiewowe w kierunku raka żołądka - czy istnieje? \\ Przegląd literatury
}

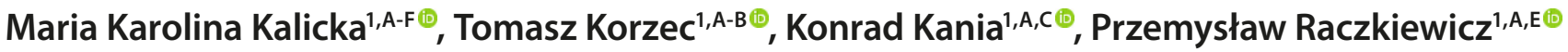 \\ ${ }^{1}$ Medical University, Lublin, Poland \\ A - Research concept and design, B - Collection and/or assembly of data, C - Data analysis and interpretation, \\ $D$ - Writing the article, E-Critical revision of the article, F - Final approval of article
}

Kalicka MK, Korzec T, Kania K, Raczkiewicz P. Gastric Cancer screening - does it exist or not? - literature review. Med Og Nauk Zdr. 2022; 28(1): 48-51. doi: 10.26444/monz/142869

\begin{abstract}
Introduction and objective. Gastric cancer (GC) is one of the biggest healthcare problems worldwide. Despite the fact that the incidence of this cancer has decreased recently, GC is in the fifth place of causes of morbidity, and in the second place of causes of mortality. Therefore, some countries such as Japan and South Korea have established and developed screening methods to detect GC as early as possible and to begin early treatment.
\end{abstract}

Materials and method. Review methods were based on articles available in the following databases: PubMed, UpToDate, among others.

Brief description of the state of knowledge. There are many types of screening methods, such as, markers of atrophy-serumpepsinogen test and low serum gastrin-17 concentration, barium photofluorography of mucosa, or endoscopy. Upper gastrointestinal endoscopy has the highest detection rate in high-incidence areas, compared to other screening methods, because upper endoscopy makes it possible to highlight changes such as flat and non-ulcerative lesions, which are usually invisible in barium examination. An alternative to screening is the massive eradication of Helicobacter pylori. Some countries occasionally recommend genetic testing and prophylactic gastrectomy.

Conclusions. Despite the high incidence of GC in Asian countries, there is still a lack of data on the cost-effectiveness of mass screening for GC. The main factor influencing the profitability of screening tests for GC is the cost of upper gastrointestinal endoscopy. Moreover, the value and usefulness of the GC screening programme remains controversial in many countries

\section{Key words}

gastric cancer, gastric cancer screening, gastric cancer markers, guidelines

\begin{abstract}
Streszczenie
Wprowadzenie i cel pracy. Rak żołądka to jeden z największych problemów zdrowotnych na świecie. Mimo że w ostatnim czasie zachorowalność na ten nowotwór zmniejszyła się, rak żołądka zajmuje piąte miejsce wśród przyczyn zachorowalności i drugie wśród przyczyn zgonów. Dlatego niektóre kraje, takie jak Japonia i Korea Południowa, zdecydowały się ustanowić i opracować metody badań przesiewowych, aby wykryć raka żołądka tak wcześnie, jak to możliwe, i jak najszybciej rozpocząć leczenie.
\end{abstract}

Metody przeglądu. Metody przeglądu stanowiły artykuły dostępne przede wszystkim w bazach PubMed i UpToDate oraz w wielu innych.

Opis stanu wiedzy. Istnieje wiele rodzajów metod badań przesiewowych w kierunku raka żołądka, takich jak: markery atrofii - test surowicy-pepsynogenu i niskie stężenie gastryny-17 w surowicy, fotofluorografia baru błony śluzowej czy endoskopia. Endoskopia górnego odcinka przewodu pokarmowego ma najwyższy wskaźnik wykrywalności w obszarach o wysokiej zachorowalności w porównaniu z innymi metodami badań przesiewowych, ponieważ umożliwia uwydatnienie zmian, takich jak zmiany płaskie i niewrzodziejące, które są zwykle niewidoczne w badaniu baru. Alternatywą dla badań przesiewowych jest masowe zwalczanie Helicobacter pylori. Niektóre kraje w tym celu zalecają czasami testy genetyczne i profilaktyczne wycięcie żołądka.

Podsumowanie. Pomimo wysokiej częstości występowania raka żołądka w krajach azjatyckich, nadal brakuje danych na temat opłacalności masowych badań przesiewowych w jego kierunku. Głównym czynnikiem wpływającym na opłacalność badań przesiewowych jest koszt endoskopii górnego odcinka przewodu pokarmowego. Ponadto wartość i użyteczność programu badań przesiewowych w kierunku raka żołądka pozostaje kontrowersyjna w wielu krajach.

\section{Słowa kluczowe}

rakżołądka, wytyczne, badania przesiewowe w kierunku raka żołądka, markery raka żołądka

\section{INTRODUCTION AND OBJECTIVE}

Nowadays, gastric cancer (GC) is one of the biggest healthcare problem worldwide. Despite the fact that the incidence of this cancer has decreased recently, it is in the fifth place of 
causes of morbidity, and in the second place of causes of mortality. [1]

Risk factors. Both environmental and genetic factors affect GC. The cirrent study distinguishes between modifiable and non-modifiable factors. The non-modifiable factors include age and gender. GC can be divided according to its location into cardia and non-cardia GC. Risk factors are presented in Table 1 [1-2].

Table 1. Risk factors for cardia and non-cardia GC

\begin{tabular}{ll}
\hline Risk factors for cardia GC & Risk factors for noncardia GC \\
\hline $\begin{array}{l}\text { Age } \\
\text { Male gender }\end{array}$ & \\
$\begin{array}{l}\text { Cigarette smoking } \\
\text { Face (depending on location) } \\
\text { Radiation }\end{array}$ & \\
\hline & \\
Obesity & Helicobacter pylori infection \\
GERD (Gastro-Oesophageal Reflux & $\begin{array}{l}\text { Low socio-economic status } \\
\text { Excesive consumption of salted and } \\
\text { sisease) }\end{array}$ \\
& $\begin{array}{l}\text { Deficiency in the consumption of } \\
\text { vegetables and fruits }\end{array}$ \\
\hline
\end{tabular}

Prevention. Gastric cancer prevention includes primary and secondary prevention. Primary prevention is based on reducing the incidence of GC. Secondary prevention is based on the earliest possible detection of the disease and the earliest possible initiation of treatment. Some methods of primary and secondary prevention of GC are presented in Table 2 [2].

Table 2. Methods of primary and secondary prevention of GC

\begin{tabular}{ll}
\hline Smoking cessation & $\begin{array}{l}\text { Elimination of one of the most common } \\
\text { causes of GC and other health diseases. }\end{array}$ \\
\hline Reducing salt intake & $\begin{array}{l}\text { Elimination of one of the risk factors for } \\
\text { GC and cardiovascular diseases. }\end{array}$ \\
\hline Increasing fruit and vegetable intake & This link is still unclear. \\
\hline $\begin{array}{l}\text { Mediterranean diet, higher intake of } \\
\text { fibres, and physical activity }\end{array}$ & This link is still unclear. \\
\hline Eradication of Helicobacter pylori & $\begin{array}{l}\text { One of the meta-analysis of 7 } \\
\text { randomized studies has demonstrated } \\
\text { that treatment of H. pylori can reduce } \\
\text { GC risk by 35\%. [3] }\end{array}$ \\
\hline Intake of NSAIDs and statins & Observational studies are still ongoing. \\
\hline Secondary prevention & $\begin{array}{l}\text { Secondary prevention is discussed in } \\
\text { detail in this article. }\end{array}$ \\
\hline
\end{tabular}

Therefore, some countries, such as Japan and South Korea, have established and developed screening methods to detect GC as early as possible and to begin early treatment aimed at preventing the serious consequences of this disease and reducing mortality [4].

\section{OBJECTIVE}

The aim of this study is to describe and discuss the effectiveness of screening methods, which however, are used in only a small part of the world. The study material consisted of publications found in the PubMed, UpToDate base and Google Scholar databases. In order to find the proper publications, the search was conducted with the use of a combination of key words, e.g. gastric cancer, gastric cancer screening, gastric cancer markers, guidlines.

\section{DESCRIPTION OF THE STATE OF KNOWLEDGE:}

It should be mentioned at the outset that the value and usefulness of a screening programme remains controversial; nevertheless, in some countries, such as: Japan, Venezuela and Chile, this strategy is being practiced. However, many countries still do not recommend screening for GC and no action is taken to make this change. [4]

Asian countries. The progression of GC from early to advanced stage is approximately 44 months. [5] The appropriate cut-off age for individual countries depend on the local incidence of GC. Asian countries are countries at high risk of GC and the cut-off age is approximately 40 years. Generally, worldwide the incidence is higher in men, which makes these tests more recommended to men over the age 40. Despite the very strong link between Helicobacter pylori infection and GC, screening tests are recommended not only for people with a positive Helicobacter pylori test, for example, gastric atrophy, which can result in the development of GC, and may reduce the detection of Helicobacter pylori in available tests. A screening programme should be also offered to first-degree relatives of patients with GC. Occasionally, some countries recommend genetic testing and prophylactic gastrectomy. [4-5]

In 1960, Japan recommended photofluorography as the only recognized screening method. In 2013, Helicobacter pylori eradication was added to the reimbursed screening programme. In Japan, upper-endoscopy and the serumpepsinogen test have become another screening method, while in South Korea, the standard screening test is photofluorography in conjuction with upper endoscopy. In addition in Korea, mass screening for GC has unfortunately not been assessed in a randomised controlled trial. Kazachstan has also established as a GC screening method bi-annual upper endoscopy for the age group 50-60. In Singapore and Taiwan screening is used effectively only at high-risk groups, by using the serum-pepsinogen test and a questionnaire, serum concentration of PGI and upper endoscopy. In China, despite the high incidence of GC, there is no GC screening programeme [4-6].

Types of screening methods. There are several types of screening methods: markers of atrophy, barium photofluorography of mucosa, or endoscopy. [5] The intestinal type of gastric cancer very often develops on the basis of atrophic gastritis. It was observed that atrophic gastritis causes a decrease in the production of a protein called - pepsinogen I. There are two immunological types of this protein - PGI and PGI; however, in atrophic gastritis PGI level decreases significantly, caused by the loss of fundic gland mucosa. Research suggests that the serum PGI/PGII ratio can be useful as a marker of the future development of GC $[5,7]$. This method, called the serum-pepsinogen test, is very popular in Japan where a PGI concentration below $70 \mathrm{mg} / \mathrm{L}$ and a PGI/PGII ratio below $3 / 0$ are the cut-off values for atrophic gastritis [7-8]. 
Chronic gastritis and atrophic gastritis caused by Helicobacter pylori, could reduce production of ghrelin, through low serum may precide GC and be used as a marker of development of GC. One of the case-control Chinese study confirmed the link between low serum gastrin-17 concentration and atrophic gastritis. What is important, level of gastrin-17 concertation did not distinguish between early and advanced GC. [9] Antigastric parietal cell antibodies may result from the process of carcinogenesis, but they are usually used in addition to other markers. [5]

As already mentioned, photofluorography has been used for screening of GC in Japan since the 1960s. Generally, compared to other screening methods, photofluorography privides the best results, although there is no published randomized trial to confirm this. Suspicious changes that should be subjected to more detailed endoscopic analysis include: decreased calibre of lumen, stenosis, deformity, rigidity, indentation, the presence of a niche or a filling defect in the wall, flattening of the randwall, barium pooling, irregularity in the gastric area, change in gastric fold, or the presence of a polypoid lesion [5]. Compared to other screening methods, upper gastrointestinal endoscopy has the highest detection rate in high-incidence areas, and is extremely popular in Japan, Venezuela and Korea. Upper endoscopy makes it possible to highlight changes, such as flat and non-ulcerative lesions, which are usually invisible in barium examination. $[2,5]$

Nowadays, there are new and more advanced types of endoscopy, thanks to which the sensitivity of detecting early gastric cancer increases. The following deserve attention: chromoendoscopy, magnifying endocscopy, narrow band imaging, and confocal endomicroscopy. Standard chromoendoscopy is performed using indigo carmine dye for contrast enhancement, which definitely makes it easier to detect gastric lesions. Indigo carmine can be applied directly to the mucosa. Another important type of endoscopy that is constantly developing is highresolution imaging - magnifying endocscopy [10]. One study, however, has shown that second-generation narrow band imaging (2G-NBI) did not increase the early gastric cancer detection rate over conventional endocsopy. Confirmatory research is still ongoing [11]. Of importance is the discovery of probe-based confocal laser endomicroscopy - pCLE), which can increase the yield of endoscopic biopsy for gastric cancer compared to white light endoscopy. The basis for this finding was the detected greater number of neoplastic cells with the use of pCLE, compared to white light endoscopy [12].

An alternative to screening is the massive eradication of Helicobacter pylori. However, only those patients whose GC is associated with $\mathrm{H}$. pylori infection would benefit from this approach. One US study showed the potential costeffectiveness of screening and eradication of Helicobacter pylori in high-risk populations. Fuhermore, it has been proven that antigastric parietal cell antibodies are strongly related to a high risk of atrophic gastritis. It is worth mentioning that this link was much stronger among Helicobacter pylorinegative patients $(\mathrm{OR}=11.3)$ than among Helicobacter pylori-positive $(\mathrm{OR}=2.6)$ patient $[3,13]$. According to the Taipei global consensus, it has been established that the eradication of $\mathrm{H}$. pylori reduces the risk of GC among asymptomatic patients. First-degree relatives of patients with GC should also be tested and if the test proves to be positive, eradication should be offered. In the future, mass screening of populations at high risk should be considered [14].

\section{CONCLUSIONS}

Despite the high incidence of GC in Asian countries, there is still a lack of data on the cost-effectiveness of mass screening for GC. According to one study from Singapore, it can be concluded that it is highly profitable to perform GC screening only in moderate and high risk groups - screening endoscopy every 2 years. The main factor influencing the profitability of screening tests for GC is the cost of upper gastrointestinal endoscopy $[5,15]$.

In conclusion, it is extremely important to search for new and more effective screening methods for GC and risk factors, so that in the future GS will not be the main cause of morbidity and mortality. Numerous studies are currently underway to determine whether mass screening programmes are cost effective and effective enough to be disseminated on a larger scale $[14,16]$.

\section{REFERENCES}

1.Eusebi LH, Telese A, Marasco G, Bazzoli F, Zagari R. Gastric cancer prevention strategies: A global perspective. Journal of Gastroenterology and Hepatology. 2020; 35(9): 1495-1502. doi: 10.1111/jgh.15037

2. Karimi P, Islami F, Anandasabapathy S, Freedman N, Kamangar F. Gastric Cancer: Descriptive Epidemiology, Risk Factors, Screening, and Prevention. Cancer Epidemiology, Biomarkers\&Prevention. 2014; 23(5): 700-713. doi: 10.1158/1055-9965.EPI-13-1057

3. Fuccio L, Zagari RM, Eusebi LH, Laterza L, Cennamo V, Ceroni L, et al. Meta-analysis: can Helicobacter pylori eradication treatment reduce the risk for gastric cancer? Annals of Internal Medicine. 2009; 151(2): 121-128. doi: 10.7326/0003-4819-151-2-200907210-00009

4. Sano, T. Gastric cancer: Asia and the world. Gastric Cancer. 2017; 20 : 1-2. doi: 10.1007/s10120-017-0694-9

5. Leung WK, Wu M, Kakugawa Y, Kim JJ, Yeoh K, Goh KL, et al. Screening for gastric cancer in Asia: current evidence and practice. The Lancet Oncology. 2008; 9(3): 279-87. doi: 10.1016/S1470-2045(08)70072-X

6. Pasechnikov V, Chukov S, Fedorov E, Kikuste I, Leja M. Gastric cancer: Prevention, screening and early diagnosis. World Journal of Gastroenterology. 2014; 20(38): 13842-13862. doi: 10.3748/wjg.v20. i38.13842

7. Hamashima C. Systematic Review Group and Guideline Development Group for Gastric Cancer Screening Guidelines. Update version of the Japanese Guidelines for Gastric Cancer Screening. Japanese Journal of Clinical Oncology. 2018; 48(7): 673-683. doi: 10.1093/jjco/hyy077

8. Chen, Xian-Zhe, Huang, Cheng-Zhi, Hu, Wei-Xian, Liu, Ying, Yao, Xue-Qing. Gastric Cancer Screening by Combined Determination of Serum Helicobacter pylori Antibody and Pepsinogen Concentrations. Chinese Medical Journal. 2018; 131(10): 1232-1239. doi: 10.4103/03666999.231512

9. Yu G, Wang GX, Wang HG, Mo FF, Tang BB. The value of detecting pepsinogen and gastrin-17 levels in serum for pre-cancerous lesion screening in gastric cancer. Neoplasma. 2019; 66(4): 637-640. doi: 10.4149/neo_2018_180825N647

10. Pérez-Mendoza A,. Zárate-Guzmán ÁM, Galvis García ES, Sobrino Cossío S, Djamus Birch J. Aplicación de la endoscopia sistemática alfanumérica codificada más cromoendoscopia para la detección de lesiones precancerosas gástricas y cáncer gástrico temprano en sujetos con riesgo promedio de cáncer gástricoSystematic alphanumeric-coded endoscopy versus chromoendoscopy for the detection of precancerous gastric lesions and early gastric cancer in subjects at average risk for gastric cancer. Revista de Gastroenterología de México. 2018; 83(2): 117-124. doi: 10.1016/j.rgmx.2017.06.004

11. Yoshida N, Doyama H, Yano T, et al. Early gastric cancer detection in high-risk patients: a multicentre randomised controlled trial on the effect of second-generation narrow band imaging. Gut. 2021; 70: 67-75. doi: 10.1136/gutjnl-2019-319631 
12. Chan Park, et al. Role of probe-based confocal laser endomicroscopytargeted biopsy in the molecular and histopathological study of gastric cancer. Journal of Gastroenterology and Hepatology. 2019; 34(1): 84-91. doi: $10.1111 /$ jgh.14471

13. Parsonnet J, Harris RA, Hack HM, Owens DK. Modelling costeffectiveness of Helicobacter pylori screening to prevent gastric cancer: a mandate for clinical trials. The Lancet. 1996; 348(9021): 150-154. doi: 10.1016/s0140-6736(96)01501-2

14. Liou JM, Malfertheiner P, Lee YC, Sheu BS, Sugano K, Cheng HC, Yeoh KG, Hsu PI, Goh KL, Mahachai V, Gotoda T, Chang WL, Chen MJ, Chiang TH, Chen CC, Wu CY, Leow AH, Wu JY, Wu DC, Hong TC, Lu H, Yamaoka Y, Megraud F, Chan FKL, Sung JJ, Lin JT, Graham
DY, Wu MS, El-Omar EM. Screening and eradication of Helicobacter pylori for gastric cancer prevention: the Taipei global consensus. Gut. 2020; 69(12): 2093-2112. doi: 10.1136/gutjnl-2020-322368

15. Zhang X, Li M, Chen S, Hu J, Guo Q, Liu R, Zheng H, Jin Z, Yuan Y, Xi Y, Hua B. Endoscopic Screening in Asian Countries Is Associated With Reduced Gastric Cancer Mortality: A Meta-analysis and Systematic Review. Gastroenterology. 2018; 155(2): 347-354. doi: 10.1053/j. gastro.2018.04.026

16. Saumoy M, Schneider Y, Shen N, Kahaleh M, Sharaiha RZ, Shah SC. Cost Effectiveness of Gastric Cancer Screening According to Race and Ethnicity. Gastroenterology. 2018; 155(3): 648-660. doi: 10.1053/j. gastro.2018.05.026 